\title{
Energochłonność pociągów zespołowych na duże prędkości
}

\begin{abstract}
$W$ artykule przedstawiono we wstępie uwagi ogólne na temat taboru kolejowego na wysokie prędkości, a następnie zestawiono charakterystykę technicznq niektórych pociagów zespołowych. Kolejne rozdziaty zawieraja sposób wyznaczania oporów ruchu takich pociagów i wyniki przykładowych obliczeń, które dalej zostaty porównane z charakterystykami wybranych pociagów zespołowych. $\mathrm{Na}$ podstawie tego materiału zostały wyznaczone wymagane moce układów napędowych i charakterystyki trakcyjne tych pociagów. W zakończeniu odniesiono się do konsekwencji wyboru systemu zasilania w odniesieniu do mocy zainstalowanej w eksploatowanych pociagach.
\end{abstract}

\section{WSTĘP}

Kolejowe pojazdy na duże prędkości są z reguły pojazdami z napędem elektrycznym. Jednymi z szybszych lokomotyw spalinowych eksploatowanymi w Europie sa niemiecka lokomotywa serii DE1024 i duńska serii ME. Obie są przeznaczone do jazdy z prędkościami maksymalnymi $160 \mathrm{~km} / \mathrm{h}$. Z zespołów trakcyjnych $\mathrm{z}$ silnikiem spalinowym najszybszy jest obecnie IC3 kolei duńskich DSB na prędkość maksymalną $180 \mathrm{~km} / \mathrm{h}$ [14]. Wynika $\mathrm{z}$ tego, że spalinowe pojazdy trakcyjne zgodnie z klasyfikacją Unii Europejskiej w zasadzie zaliczone są do systemu kolei konwencjonalnych (Conventional Railway) [25].

Lokomotywy i zespoły trakcyjne (pociagi zespołowe - train sets) na prędkość powyżej $190 \mathrm{~km} / \mathrm{h}$ zaliczane do systemu kolei wysokich prędkości (Hight Speed) budowane są z elektrycznym napędem trakcyjnym zasilanym z sieci napowietrznej i nic nie wskazuje, by ta tendencja miała się w najbliższej przyszłości zmienić.

Pociagi dużych prędkości wymagają zainstalowania odpowiednio dużych mocy, co zostanie wykazane w dalszej części artykułu. Wprowadzenie do pojazdu tak znacznych mocy elektrycznych, ich przetworzenie i dystrybucja wymaga rozwiązania kilku problemów konstrukcyjnych, między innymi:

- wyboru jednego ze znormalizowanych, najkorzystniejszego systemu zasilania (poziomu napięcia) sieci trakcyjnej

- wyznaczenia właściwego napięcia zasilania silników trakcyjnych dla optymalnego doboru układu silnik trakcyjny - przekształtnik trakcyjny

- przeniesienia mocy przez ruchomy zestyk pantograf - sieć trakcyjna, podlegający w trakcie jazdy ciagłym zmianom dynamicznym, zarówno elektrycznym jak i mechanicznym niezawodnego, szybkiego zabezpieczenia urządzeń elektrycznych na pojeździe przed przeciążeniami i zwarciami za pomocą wyłącznika szybkiego minimalizowania strat, zwłaszcza $\mathrm{w}$ urządzeniach przetwarzających energię elektryczną (transformatory, przekształtniki, silniki) w celu racjonalizowania poboru energii oraz ograniczenia gabarytów i mas elementów systemu chłodzącego te urządzenia ograniczenia prądów zakłócających sieć trakcyjną w wyniku odkształcenia napięć przetwarzanych w przekształtnikach impulsowych oraz zakłócających urządzenia przytorowe sterowania ruchem kolejowym.

Poprawne rozwiązanie tych zagadnień w konstrukcji układów elektrycznych pojazdów kolejowych na duże prędkości wymaga wyznaczenia niezbędnych zakresów ich mocy. Sposób ich wyznaczania jest jednym z wątków niniejszego artykułu. Część z tych problemów była $\mathrm{z}$ powodzeniem rozwiązywana $\mathrm{w}$ procesie konstruowania pojazdów trakcyjnych kolei konwencjonalnych. Przy dużych prędkościach powstają dodatkowe problemy konstrukcyjne, które muszą pokonać projektanci i producenci taboru kolejowego.

\section{CHARAKTERYSTYKA TECHNICZNA WY- BRANYCH POCIĄGÓW ZESPOŁOWYCH}

Dla wyznaczenia niezbędnej dla określonej prędkości mocy pociagów zespołowych i późniejszego ich porównania celowe jest zestawienie tych cech pociągów, które wpływają na opory ruchu, a w efekcie na zainstalowaną $\mathrm{W}$ pojeździe niezbędną moc. Takie zestawienie parametrów zawierają tablice $1 \div 3[9,19$, 26]. 
Tablica 1.

\begin{tabular}{|c|c|c|c|c|c|c|c|c|c|c|c|c|}
\hline \multirow[t]{3}{*}{ Skład } & \multirow[t]{3}{*}{ Rok dostawy } & \multirow{3}{*}{$\begin{array}{l}\text { Liczba } \\
\text { [szt.] }\end{array}$} & \multirow{3}{*}{$\begin{array}{c}V_{\max } \\
{[\mathrm{km} / \mathrm{h}]}\end{array}$} & \multicolumn{2}{|c|}{ Wagony w sktadzie } & \multirow{3}{*}{$\begin{array}{c}\text { Długość } \\
\text { skfadu } \\
\text { [m] }\end{array}$} & \multirow{3}{*}{$\begin{array}{l}\text { Pojemnośc } \\
\text { sktadu } \\
\text { [I. miejsc] }\end{array}$} & \multirow[t]{3}{*}{ Zasilanie } & \multirow{3}{*}{$\begin{array}{c}\text { Masa w stanie } \\
\text { sluzbowym } \\
\text { [t] }\end{array}$} & \multirow{3}{*}{$\begin{array}{c}\text { Nacisk } \\
\text { na os } \\
{[t]}\end{array}$} & \multirow{3}{*}{$\begin{array}{c}\text { Moc ciaggla } \\
{[\mathrm{kW}]}\end{array}$} & \multirow{3}{*}{$\begin{array}{r}\text { Maks. prze- } \\
\text { chył nad- } \\
\text { wozia [\%०] }\end{array}$} \\
\hline & & & & silnikowe & doczepne & & & & & & & \\
\hline & & & & \multicolumn{2}{|c|}{ [szt.] } & & & & & & & \\
\hline ETR 450 & $1987-1998$ & 15 & 250 & 1 & 8 & 208 & 390 & $3 \mathrm{kV}$ & 435 & 13,0 & 4700 & 8 \\
\hline \multirow{2}{*}{ ETR 460} & 1994 & 7 & \multirow{2}{*}{250} & \multirow{2}{*}{3} & \multirow{2}{*}{6} & \multirow{2}{*}{237} & \multirow{2}{*}{448} & $3 \mathrm{kV}$ & \multirow{2}{*}{433} & \multirow{2}{*}{14,6} & \multirow{2}{*}{5880} & \multirow{2}{*}{8} \\
\hline & 1995-1996 & 3 & & & & & & $3 \mathrm{kV} / 1,5 \mathrm{kV}$ & & & & \\
\hline ETR 480 & 1997 & 15 & 250 & 3 & 6 & 237 & $480 / 492$ & $3 \mathrm{kV}, 25 \mathrm{kV} 50 \mathrm{~Hz}$ & 433 & 14,5 & 5880 & 8 \\
\hline ETR $470^{\star}$ & 1996 & 9 & 200 & 5 & 4 & 237 & 504 & $3 \mathrm{kV}, 15 \mathrm{kV} 16^{2} / 3 \mathrm{~Hz}$ & 450 & 14,5 & 5880 & 8 \\
\hline \multirow{4}{*}{ ETR 500} & 1991 & 2 & \multirow{4}{*}{300} & \multirow{4}{*}{2} & 10 & 302 & 672 & \multirow{2}{*}{$3 \mathrm{kV}$} & 556 & 19,0 & 8500 & \multirow{4}{*}{0} \\
\hline & 1995-1997 & 30 & & & 11 & 328 & 663 & & 642 & \multirow{3}{*}{17,0} & \multirow{3}{*}{8800} & \\
\hline & 1997-1999 & 10 & & & 8 & 250 & 490 & \multirow{2}{*}{$3 \mathrm{kV}, 25 \mathrm{kV} 50 \mathrm{~Hz}$} & 472 & & & \\
\hline & 1997-1999 & 20 & & & 11 & 328 & 663 & & 642 & & & \\
\hline Pendolino nuovo & 2006-2007 & 12 & 250 & 4 & 3 & 188 & 432 & $3 \mathrm{kV}, 25 \mathrm{kV} 50 \mathrm{~Hz}$ & 443 & 17,0 & 5500 & 8 \\
\hline Pendolino Cisalpino & $2006-2007$ & 14 & 250 & 4 & 3 & 188 & 431 & $\begin{array}{c}3 \mathrm{kV}, 25 \mathrm{kV} 50 \mathrm{~Hz} \\
15 \mathrm{kV} 16^{2} / 3 \mathrm{~Hz}\end{array}$ & 450 & 17,0 & 5500 & 8 \\
\hline
\end{tabular}

Tablica 2.

Dane pociągów ICE

\begin{tabular}{lccccc} 
Typ pociaggu & & ICE 1 & ICE 2 & $\begin{array}{c}\text { ICE 3 } \\
\text { 1-systemowy }\end{array}$ & $\begin{array}{c}\text { ICE 3 } \\
\text { 4-systemowy }\end{array}$ \\
Rok budowy & & 1990 & 1997 & 1999 & 1999 \\
\hline Prędkość maksymalna & {$[\mathrm{km} / \mathrm{h}]$} & 280 & 300 & 330 & 300 \\
\hline Układ wagonów & & $2 \mathrm{~s}+12 \mathrm{~d}$ & $1 \mathrm{~s}+7 \mathrm{~d}$ & $4 \mathrm{~s}+4 \mathrm{~d}$ & $4 \mathrm{~s}+4 \mathrm{~d}$ \\
\hline Liczba miejsc do siedzenia & $192+435$ & $105+263$ & $136+244$ & 390 \\
\hline Moc & {$[\mathrm{kW}]$} & 9600 & 4800 & 8000 & 8000 \\
\hline Długość & {$[\mathrm{m}]$} & 358 & 205 & 200 & 200 \\
\hline Masa & {$[\mathrm{t}]$} & 795 & 410 & 409 & 435 \\
\hline Zasilanie & {$[\mathrm{kW}]$} & 15 & 15 & 15 & $15 / 25 / 3 / 1,5$ \\
\hline Operator & & $D B$ & $D B$ & $D B$ & $D B$
\end{tabular}

Tablica 3.

Dane pociągów TGV

\begin{tabular}{|c|c|c|c|c|c|c|c|c|c|c|}
\hline Typ pociagu & TGV-PSE & TGV-A & TGV-R & Eurostar & Thalys & TGV-D & AVE & TGV Korea & TGV-POS & AGV \\
\hline Rok budowy & 1978 & 1989 & 1992 & 1994 & 1997 & 1997 & 1991 & 2002 & 2007 & Prototyp od 2001 \\
\hline Prędkość maksymalna [ $[\mathrm{km} / \mathrm{h}]$ & 270 & 300 & 300 & 300 & 300 & 320 & 300 & 300 & 320 & $320-350$ \\
\hline Układ wagonów & $2 s+8 d$ & $2 s+10 d$ & $2 s+8 d$ & $2 s+18 d$ & $2 s+8 d$ & $2 s+8 d$ & $2 s+8 d$ & $2 s+16 d$ & $2 s+8 d$ & do 11 \\
\hline Liczba miejsc do siedzenia & $108+260$ & $116+369$ & $120+257$ & $210+560$ & $120+257$ & $197+384$ & $116+213$ & 935 & $120+257$ & do 465 \\
\hline$[\mathrm{kW}]$ & 6420 & 8800 & 8800 & 12240 & 8800 & 8800 & 8800 & 13200 & 9600 & od 2800 \\
\hline Rodzaj napędu & Prąd stały & $\begin{array}{l}\text { Synchro- } \\
\text { niczny }\end{array}$ & $\begin{array}{l}\text { Synchro- } \\
\text { niczny }\end{array}$ & $\begin{array}{l}\text { Synchro- } \\
\text { niczny }\end{array}$ & $\begin{array}{l}\text { Synchro- } \\
\text { niczny }\end{array}$ & $\begin{array}{c}\text { Synchro- } \\
\text { niczny }\end{array}$ & $\begin{array}{l}\text { Synchro- } \\
\text { niczny }\end{array}$ & $\begin{array}{l}\text { Synchro- } \\
\text { niczny }\end{array}$ & $\begin{array}{l}\text { Asynchro- } \\
\text { niczny }\end{array}$ & $\begin{array}{l}\text { Asynchroniczny } \\
\text { z silnikami z mag- } \\
\text { nesami stałymi }\end{array}$ \\
\hline Długość & 200 & 238 & 200 & 394 & 200 & 200 & 200 & 393 & 200 & $132-201$ \\
\hline Masa & 385 & 484 & 386 & 752 & 386 & 380 & 392 & 750 & 389 & \\
\hline Zasilanie & $25 / 15 / 1,5$ & $25 / 1,5$ & $25 / 3 / 1,5$ & $\begin{array}{c}25 / 3 / 1,5 / \\
/ 0,75\end{array}$ & $\begin{array}{l}25 / 15 / 3 / \\
/ 1,5 / 0,75\end{array}$ & $25 / 1,5$ & $25 / 3$ & $25(60 \mathrm{~Hz})$ & $25 / 15 / 1,5$ & $25 / 15 / 3 / 1,5$ \\
\hline Operator & SNCF & SNCF & SNCF & Eurostar & Thalys & SNCF & RENFE & Korea & SNCF & \\
\hline
\end{tabular}

3. OPORY RUCHU ELEKTRYCZNYCH POJAZDÓW TRAKCYJNYCH

Dobór mocy elektrycznych pojazdów trakcyjnych kolei konwencjonalnej do prędkości $190 \mathrm{~km} / \mathrm{h}$ nie nastręcza wielu problemów. Niewielkie nawet błędy w wyznaczeniu oporów ruchu, które są podstawą określenia wymaganej charakterystyki trakcyjnej, nie mają istotnego znaczenia dla doboru mocy. Nie jest tu nawet istotna metoda wyznaczenia mocy napędu [6]. We wszystkich metodach dotyczących wysokich prędkości kluczową sprawą jest dokładność odwzorowania wszystkich składników oporów ruchu.
Jedną z lepiej znanych z literatury zależnością na wyznaczanie oporów ruchu odnoszącą się jednoznacznie do pociagów zespołowych jest niżej podany wzór opublikowany przez Petersa [16], opracowany i zweryfikowany dla pociagu zespołowego ICE [20]:

$$
\begin{aligned}
\mathrm{F}= & 1.14 \cdot \mathrm{M}+(0.0025 \cdot \mathrm{M}-0.32+1.39 \cdot \hat{\mathrm{n}}) \cdot \mathrm{v}+ \\
& +(0.0156+0.0037 \cdot \mathrm{n}) \cdot \dot{\mathrm{n}} \cdot \mathrm{T}_{\mathrm{f}} \cdot(\mathrm{v}+\mathrm{b})^{2},
\end{aligned}
$$

przy czym:

$\mathrm{F}$ - zasadnicze opory ruchu pociagu [daN], $\mathrm{M}$ - całkowita masa pociagu (wagonów) [t], ń - masa właściwa powietrza $\left[\mathrm{kg} / \mathrm{m}^{3}\right]$, 
$\mathrm{v}$ - prędkość pociagu $[\mathrm{km} / \mathrm{h}]$,

$\mathrm{n}$ - liczba wagonów między członami napędnymi,

$\mathrm{T}_{\mathrm{f}}-$ współczynnik korekcyjny

dla torów na otwartej przestrzeni $=1$,

$\mathrm{w}$ tunelu $=1.56-0.07 \cdot \mathrm{n}$,

b - prędkość wiatru przeciwnego do kierunku jazdy, przyjmuje się statystycznie $15 \mathrm{~km} / \mathrm{h}$.

$$
\rho=1.2255 \cdot \frac{p}{1013} \cdot \frac{288}{273+v},
$$

gdzie:

$$
\begin{aligned}
& \mathrm{p} \text { - ciśnienia atmosferyczne, } \\
& v \text { - temperatura powietrza }\left[{ }^{\circ} \mathrm{C}\right]
\end{aligned}
$$

Wzory odnoszące się do klasycznych (konwencjonalnych) e.z.t. stosowane dotąd na PKP mają postać [11]:

$$
\begin{gathered}
F=(0.64+0.0147 \cdot v) \cdot M+ \\
+14.7 \cdot z+0.01 \cdot(2.7+n) \cdot v^{2},
\end{gathered}
$$

gdzie:

$\mathrm{z}$ - liczba osi wagonów pociąu, a pozostałe oznaczenia jak we worze (1).

Dla pociagów składających się z pojedynczych wagonów ciągniętych lokomotywą w dostępnej literaturze brak jest aktualnie wzorów na opory ruchu dla wysokich prędkości ponad $190 \mathrm{~km} / \mathrm{h}$. Do analiz, mając świadomość błędu obliczeń zwiększającego się w miarę wzrostu prędkości, można przyjmować zależności stosowane na PKP oraz zalecane przez UIC.

Dla lokomotywy dostępne są następujące zależności wyrażone w $\mathrm{kN}[1,2,24]$ :

$$
\begin{gathered}
\mathrm{R}=\left(12-0.024 \cdot \mathrm{v}+0.0074 \cdot \mathrm{v}^{2}\right) \cdot \mathrm{m} \cdot 10^{-3}, \\
\mathrm{R}=0.0294 \cdot \mathrm{m}+0.000294 \cdot \mathrm{v}^{2},
\end{gathered}
$$

gdzie:

$\mathrm{m}$ - masa lokomotywy w $[\mathrm{t}]$,

a zależności wyrażone $\mathrm{w}$ daN dla nowoczesnych wagonów mają postać $[17,18]$ :

$$
\begin{aligned}
& \mathrm{W}=0.85 \cdot \mathrm{M}+15.6 \cdot \mathrm{z}+0.0072 \cdot(\mathrm{n}+2.5) \cdot \mathrm{v}^{2}, \\
& \mathrm{~W}=(0.64+0.029 \cdot \mathrm{v}) \cdot \mathrm{M}+11.7 \cdot \mathrm{z}+ \\
& +0.0059 \cdot(\mathrm{n}+2.5) \cdot \mathrm{v}^{2}, \\
& \mathrm{~W}=(0.64+0.0147 \cdot \mathrm{v}) \cdot \mathrm{M}+14.7 \cdot \mathrm{z}+ \\
& +0.00785 \cdot(\mathrm{n}+2.5) \cdot \mathrm{v}^{2} \text {, }
\end{aligned}
$$

w których oznaczenia są takie same jak we wzorach $1 \div 3$.

Do analizy liczbowej przyjęto dwa przykładowe pociagi odpowiadające sobie pod względem liczby wagonów, jeden z lokomotywą typu 110E [4], ciagnącą wagony osobowe typu 150A [15] i drugi, tzw. pociagg zespołowy typu ICE. Dane tych pociagów zestawiono w tablicy 4 , a wykorzystywane w obliczeniach wg powyższych wzorów wythuszczono:

Na podstawie danych do wzorów $(1 \div 8)$ i sprowadzeniu do wspólnej jednostki $[\mathrm{kN}]$ oraz po uporządkowaniu uzyskano następujące, praktyczne zależności:

a) dla pociagów zespołowych:

$$
\begin{gathered}
\mathrm{F}=10.2828+0.04278 \cdot \mathrm{v}+0.000826 \cdot(\mathrm{v}+15)^{2} \\
\left(\text { dla } 15^{\circ} \mathrm{C} \text { i } 1013 \mathrm{hPa}\right) \\
\mathrm{F}=12.3536+0.094668 \cdot \mathrm{v}+0.00167 \cdot \mathrm{v}^{2}
\end{gathered}
$$

\begin{tabular}{|c|c|c|c|c|c|}
\hline \multicolumn{3}{|c|}{ Pociąg zespołowy ICE } & \multicolumn{3}{|c|}{ Pociąg klasyczny 110E + 14 150A } \\
\hline $\begin{array}{ll}\text { masa } & \text { całkowita } \\
\mathbf{M} & \\
\end{array}$ & 902 & $\mathrm{t}$ & masa lokomotywy $\mathbf{m}$ & 82 & $\mathrm{t}$ \\
\hline długość pociągu & 410.7 & $\mathrm{~m}$ & moc lokomotywy & 6 & MW \\
\hline liczba miejsc & 759 & - & liczba silników & 4 & szt. \\
\hline $\begin{array}{ll}\text { liczba } & \text { wagonów } \\
\mathbf{n} & \end{array}$ & 14 & szt. & prędkość maksymalna & 200 & $\mathrm{~km} / \mathrm{h}$ \\
\hline $\begin{array}{l}\text { liczba członów napędo- } \\
\text { wych }\end{array}$ & 2 & szt. & masa wagonu & 51.4 & $\mathrm{t}$ \\
\hline liczba silników & 8 & szt. & długość wagonu & 26.4 & $\mathrm{~m}$ \\
\hline prędkość maksymalna & 280 & $\mathrm{~km} / \mathrm{h}$ & liczba miejsc & 80 & \\
\hline moc napędna & 9.6 & MW & prędkość maksymalna & 200 & $\mathrm{~km} / \mathrm{h}$ \\
\hline & & & Liczba wagonów & 14 & szt \\
\hline & & & masa pociągu & 719,6 & $\mathrm{t}$ \\
\hline & & & liczba osi & 56 & szt. \\
\hline
\end{tabular}

a) dla lokomotyw:

$$
\begin{gathered}
\mathrm{R}=0.984-0.01968 \cdot \mathrm{v}+0.0006068 \cdot \mathrm{v}^{2}, \\
\mathrm{R}=2.4108+0.000294 \cdot \mathrm{v}^{2},
\end{gathered}
$$

a) dla wagonów pasażerskich:

$$
\begin{gathered}
\mathrm{W}=14.21+0.001188 \cdot \mathrm{v}^{2}, \\
\mathrm{~W}=10.6736+0.18676 \cdot \mathrm{v}+0.0009735 \cdot \mathrm{v}^{2}, \\
\mathrm{~W}=12.3536+0.094668 \cdot \mathrm{v}+0.00129525 \cdot \mathrm{v}^{2} .
\end{gathered}
$$

Tablica 4. Dane przykladowych pociągów 


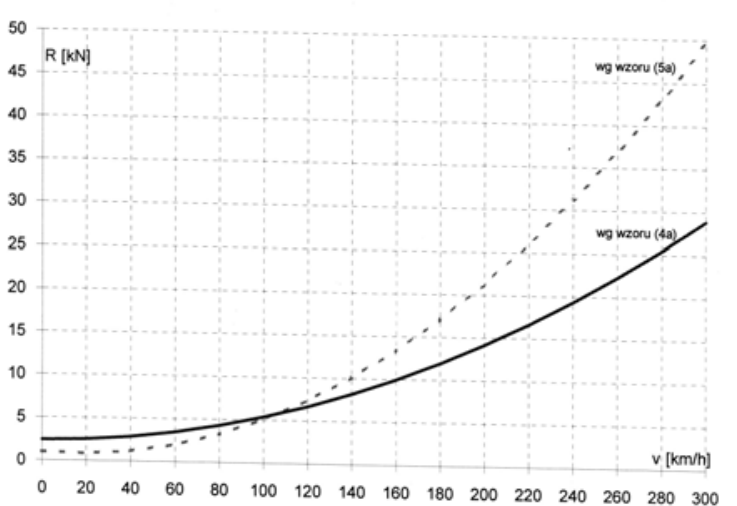

Rys. 1. Opory ruchu lokomotywy elektrycznej

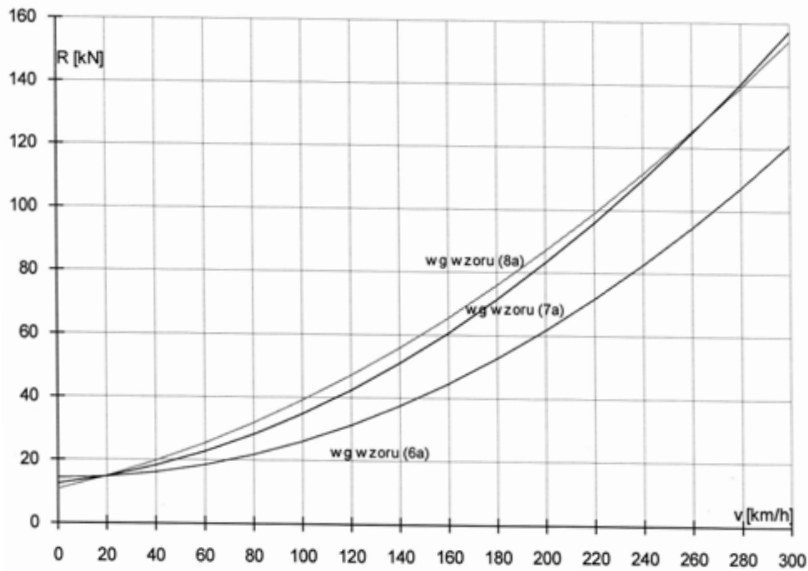

Rys. 2. Opory ruchu wagonów osobowych (14 szt.)

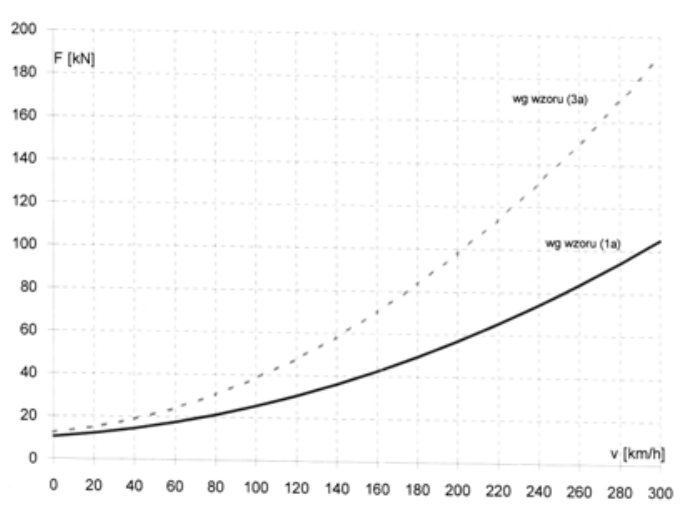

Rys. 3. Opory ruchu pociagu zespołowego

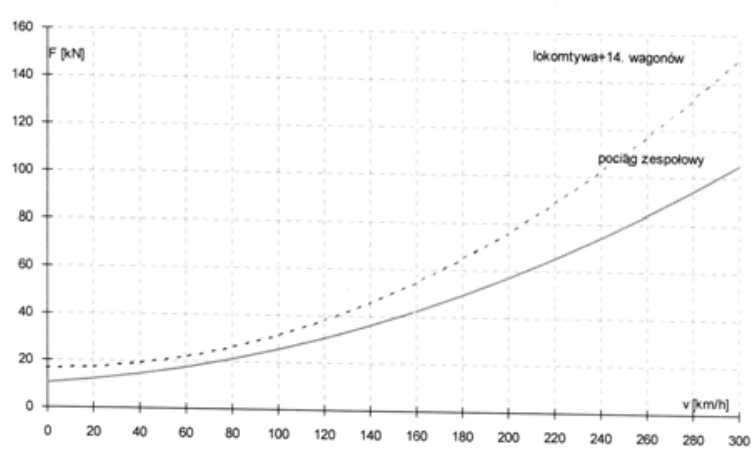

Rys. 4. Porównanie oporów ruchu pociągów
Przedstawione krzywe wykazują silną zależność krzywej oporów ruchu nie tylko od prędkości, szczególnie przy prędkościach dużych, ale także od rodzaju taboru. Tabor nowoczesny charakteryzuje się zdecydowanie korzystniejszym przebiegiem krzywej oporów ruchu.

Do dalszej analizy przyjęto krzywą wg wzoru (1a) dla pociagu zespołowego oraz sumę oporów ruchu lokomotywy (krzywa wg 4a) i dla wagonów (krzywa wg 6a). Sumaryczny przebieg pozwalający dokonać porównania przedstawiono na rys. 4. W rozpatrywanym wyżej porównaniu pociąu klasycznego i zespołowego jest to ok. $45 \mathrm{kN}$ różnicy przy prędkości $300 \mathrm{~km} / \mathrm{h}$, czyli w porównaniu z klasycznym pociągiem ciagniętym lokomotywą, opory ruchu pociagu zespołowego są około $30 \%$ mniejsze.

$\mathrm{Na}$ rys. 5 przedstawiono przebieg jednostkowych oporów ruchu dla pociagu zespołowego ETR 500 o masie 650 t [23], z kolei na rys. 6 przedstawiono porównanie oporów ruchu pociągów zespołowych: TGV - Atlantique, TGV - PSE (Paris - Sud - Est) i dwóch zestawów ICE [12]. Bardzo szybki wzrost oporów ruchu pojazdów na duże prędkości przy prędkościach ponad $200 \mathrm{~km} / \mathrm{h}$ wynika głównie $\mathrm{z}$ rosnącego udziału oporów aerodynamicznych [8].

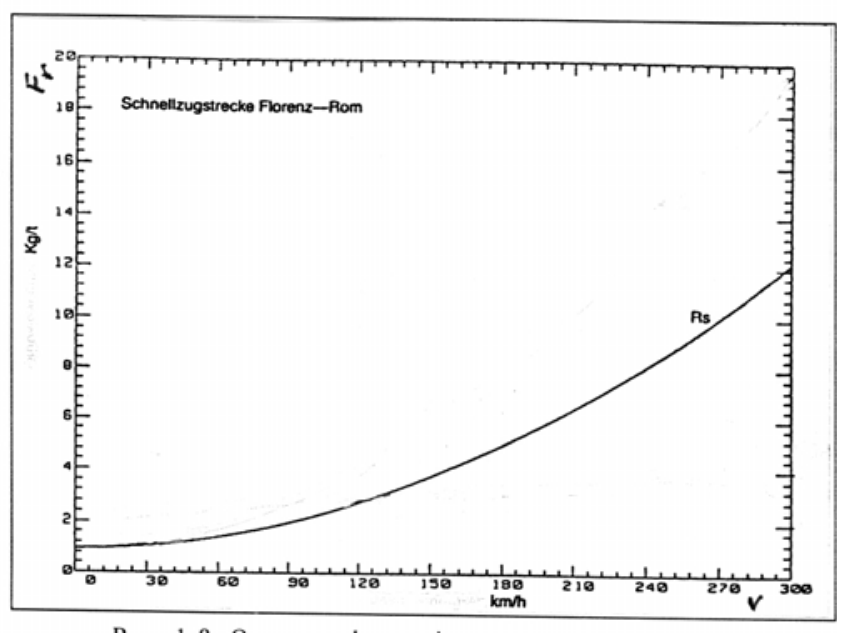

Rys. 5. Opory ruchu pociągu zespołowego ETR500

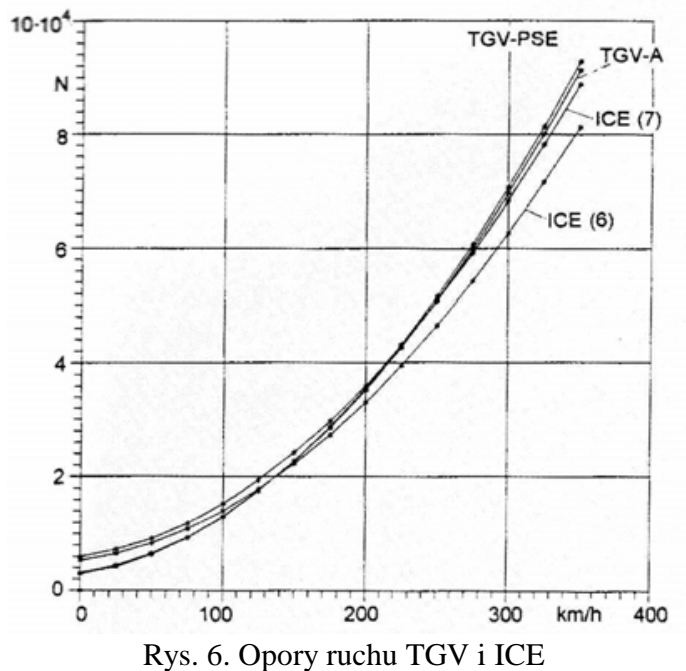

POJAZDY SZYNOWE NR 3/2010 
Rozdział oporów ruchu dla pociągu KLEW [3] greckich kolei państwowych z podziałem na opory toczenia (rollwiderstand), chwilowe (impulswiderstand) i powietrza (luftwiderstand) przedstawiono na rys. 7.

Dla pociągów wysokich prędkości wyraźnie widać silną zależność oporów ruchu, a zatem i rozwijanej maksymalnej prędkości od pionowego profilu trasy. Przykładowo na rys. 8 dla hiszpańskiego pociągu AVE S103 podano, że dla profilu 3 \%o maksymalna prędkość z $350 \mathrm{~km} / \mathrm{h}$ maleje do $190 \mathrm{~km} / \mathrm{h}$ [21].

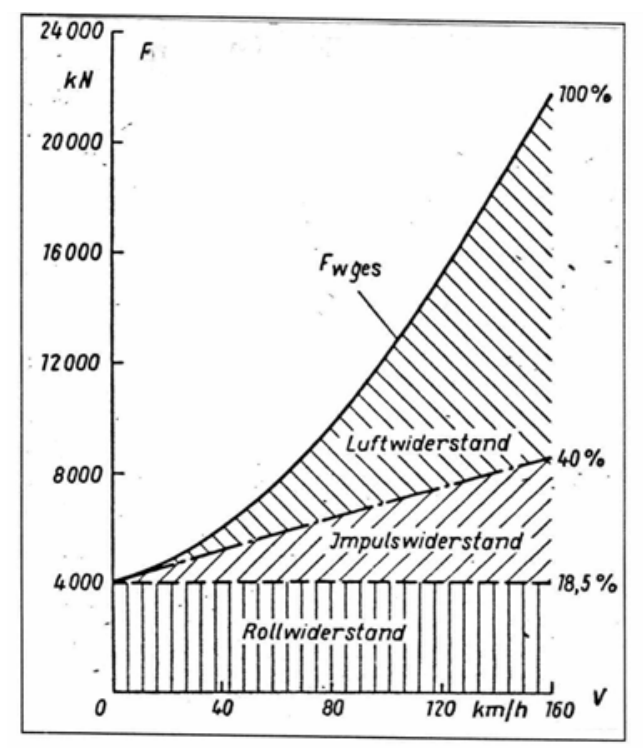

Rys. 7. Rozdział oporów ruchu

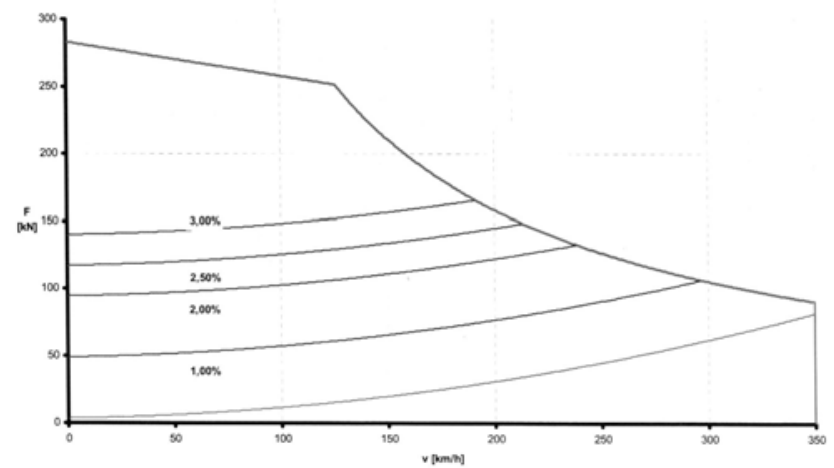

Rys. 8. Zależność oporów ruchu AVE S103 od profilu trasy

\section{OKREŚLENIE MOCY ELEKTRYCZNYCH PO- CIĄGÓW ZESPOŁOWYCH}

Przedstawione przebiegi oporów ruchu po uwzględnieniu koniecznego zapasu siły rozruchowej dla pokonania dodatkowych oporów ruchu związanych z wzniesieniami, tukami lub tunelami, pozwalają wyznaczyć niezbędne moce napędu trakcyjnego tych pojazdów. Warto zwrócić uwagę na znaczący wpływ kształtu czoła (,nos delfina”) i połączenia wagonów pociagów zespołowych na obniżenie ich oporów ruchu.
Do dalszej analizy liczbowej przyjęto charakterystyki przedstawione na rys. 4. Moc niezbędna do rozwinięcia przez pojazd wymaganej prędkości $\mathrm{v}$ (czyli do pokonania odpowiadających jej oporów ruchu $\mathrm{F}$ z niezbędnym zapasem siły przyśpieszającej przyjmowanym zgodnie z praktyką ok. $10 \%$ ) może być wyznaczona $z$ prostej zależności:

gdzie:

$$
P=\frac{1.1 \cdot F \cdot v}{3.6}
$$

F - opory ruchu pociagu wg danych dla wykresu na rys. 4 powiększone o $10 \%[\mathrm{kN}]$, $\mathrm{v}$ - prędkość $[\mathrm{km} / \mathrm{h}]$.

Wykres wymaganej mocy przedstawiono na rys. 9, a na rys. 10 przedstawiono zależność wymaganych mocy jednostkowych $[\mathrm{kW} / \mathrm{t}]$ dla pociagów na duże prędkości [7].

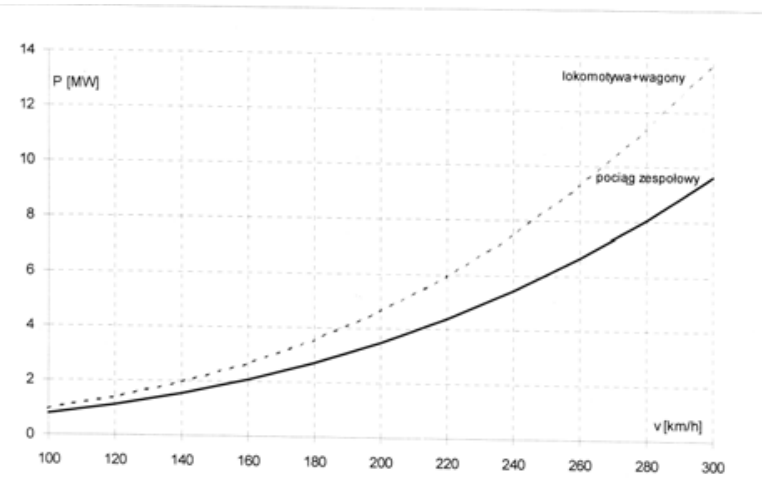

Rys. 9. Wymagana moc napędu w funkcji prędkości

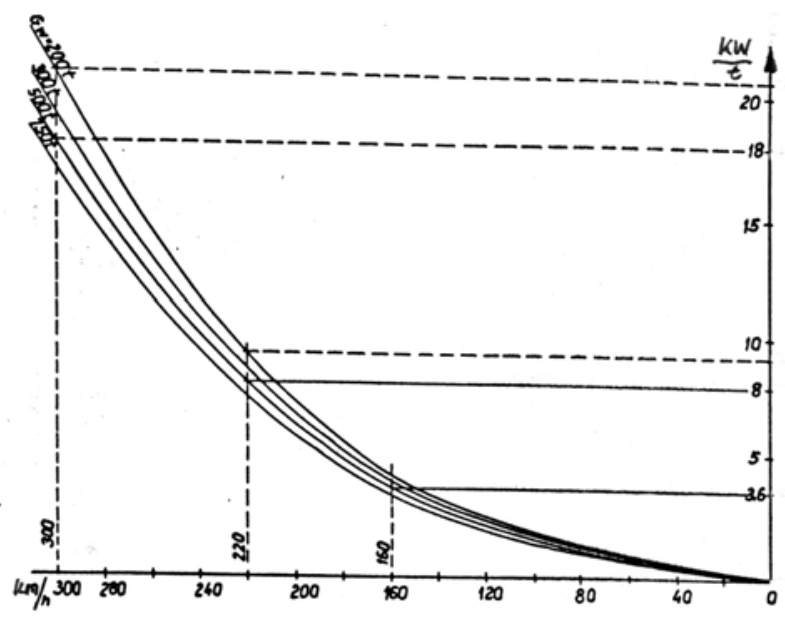

Rys. 10. Jednostkowe moce pociągów zespołowych

Uzyskane wyniki są zbieżne z wyznaczonymi metodą przedstawioną powyżej. Potwierdzenie poprawności uzyskanych wyników można uzyskać także analizując dostępne w literaturze dane niektórych pojazdów. Z charakterystyki trakcyjnej pociągu zespołowego serii 300 „Nozomi” wynika, że opory ruchu dla prędkości $300 \mathrm{~km} / \mathrm{h}$ dla pociągu o danych: 
- liczba wagonów napędnych

- liczba wagonów tocznych

- masa pociagu

- długość

10

6

$768 \mathrm{t}$

$400 \mathrm{~m}$,

wynoszą $110 \mathrm{kN}$, co przy przyjęciu $40 \%$ zapasu odpowiada mocy minimalnej 11.55 MW. Moc tego pociagu zespołowego wynosi $12 \mathrm{MW}$ (10 wagonów z 4. silnikami po $300 \mathrm{~kW}$ ). Zainstalowana moc została dobrana dla założonego przyśpieszenia rozruchu na poziomie $0.45 \mathrm{~m} / \mathrm{s}^{2}$ utrzymywanego do prędkości ok. $130 \mathrm{~km} / \mathrm{h} \mathrm{[10].}$

Dla pociagu zespołowego ETR 500 o łącznej masie 650 t, składającego się z 2 członów napędowych i 10 wagonów doczepnych, dla jednostkowych oporów ruchu na trasie Florencja - Rzym oszacowanych na poziomie $12.2 \mathrm{kG} / \mathrm{t}$ przy prędkości $300 \mathrm{~km} / \mathrm{h}$, minimalna wymagana moc wynosi 7.2 MW, ale także dla tego pociagu zainstalowana moc jest większa -8.8 MW. Pozwala to uzyskać zarówno odpowiednią moc rozruchową jak i zakres prędkości, do którego utrzymywane jest stałe przyśpieszenie.

Warta podkreślenia jest zależność mocy maksymalnej rozwijanej przez pociagi zespołowe od systemu zasilającego. Najkorzystniej wypada sieć prądu przemiennego $15 \mathrm{kV}-16.67 \mathrm{~Hz}$ i $25 \mathrm{kV}-50 \mathrm{~Hz}$. Znajduje to także odzwierciedlenie w zestawieniu dopuszczalnych prądów obciążenia przewidywanych w kolejowej sieci europejskiej dla różnych systemów, przedstawionym w tabl. 5 [19]. Na kolejnych rysunkach $11 \div 14$ przedstawiono charakterystyki trakcyjne kilku wybranych pociaggów zespołowych dla różnych mocy wynikających z systemów zasilania.

Tablica 5. Dopuszczalne prądy systemów zasilania

\begin{tabular}{cccc} 
System zasilania & \multicolumn{3}{c}{ Linie } \\
\cline { 2 - 4 } & dużych prędkości & zmodernizowane & lączące \\
DC $750 \mathrm{~V}$ & - & - & 6800 \\
\hline DC $1500 \mathrm{~V}$ & - & 5000 & 5000 \\
\hline DC $3000 \mathrm{~V}$ & 4000 & 4000 & 2500 \\
\hline AC $15 \mathrm{kV} 16,7 \mathrm{~Hz}$ & 1700 & 1000 & 900 \\
\hline AC $25 \mathrm{kV} 50 \mathrm{~Hz}$ & 1500 & 600 & 500 \\
\hline
\end{tabular}

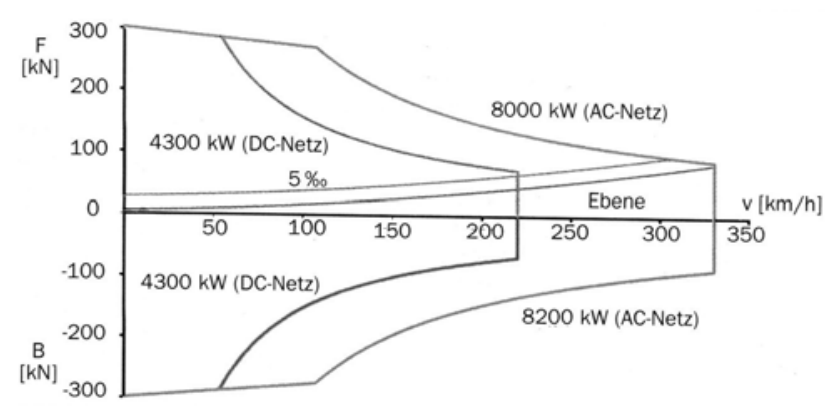

Rys. 11. Charakterystyki trakcyjne pociagu ICE [13]

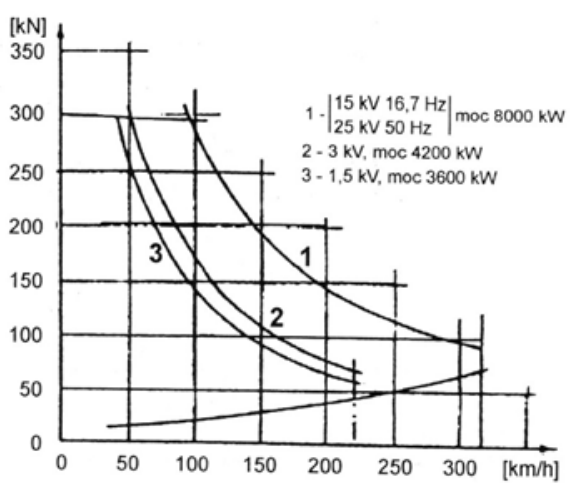

Rys. 12. Charakterystyki trakcyjne pociagu ICE3 [22]

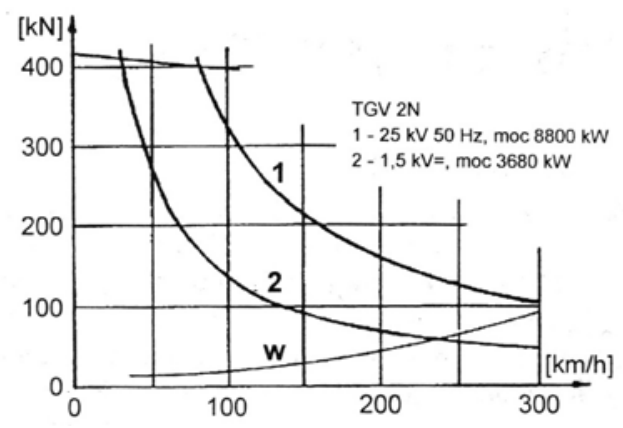

Rys. 13. Charakterystyki trakcyjne pociągu TGV 2N [22]

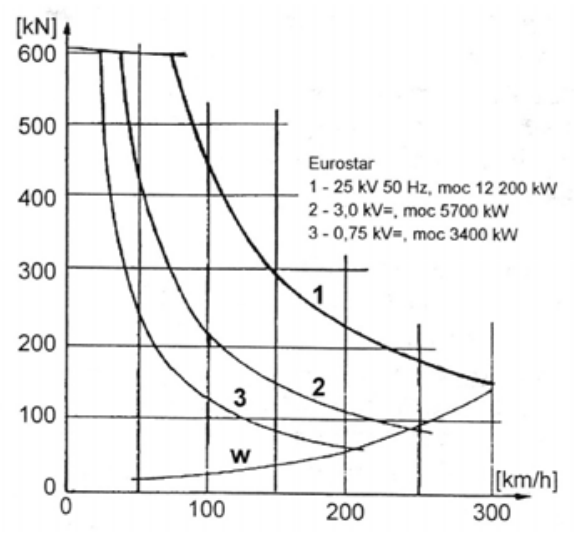

Rys. 14. Charakterystyki trakcyjne pociagu Eurostar [22]

Należy zwrócić uwagę na fakt, że cytowane w artykule wartości mocy odnoszą się do napędów trakcyjnych (moce mechaniczne na styku koła pojazdu szyny), natomiast wartości dopuszczalnych prądów systemów zasilania (podane w tabl. 5) określają maksymalne moce elektryczne pobierane przez pojazdy. Moce elektryczne są oczywiście większe od mocy mechanicznych ze względu na:

- występowanie strat w urządzeniach przekształtnikowych i samych silnikach trakcyjnych; sprawność współczesnych napędów przekształtnikowych z silnikami prądu przemiennego przekracza $90 \%$,

- istnienie poboru mocy przez systemy pomocnicze (klimatyzacyjne, oświetleniowe, sterujące itd.). 


\section{PODSUMOWANIE I WNIOSKI}

$\mathrm{Z}$ przedstawionych na wykresach charakterystyk można wyciagnąć następujące spostrzeżenia:

- wymagana moc dla prędkości $200 \mathrm{~km} / \mathrm{h}$ dla pociągu klasycznego i porównywalnego pojemnością pociagu zespołowego wynosi odpowiednio ok. 4.6 MW i $3.5 \mathrm{MW}$ (różnica $24 \%$ ), a dla prędkości ok. $300 \mathrm{~km} / \mathrm{h}$ dla pociagu klasycznego i pociagu zespołowego wynosiłaby odpowiednio ok. 13.8 MW i 9.6 MW (różnica $30 \%$ )

- wymagana moc dla pociagu zespołowego, wyznaczona w przedstawionej w niniejszym artykule analizie, pokrywa się dokładnie $\mathrm{z}$ mocą zainstalowaną $\mathrm{w}$ układzie napędowym pociągu ICE (9.6 MW),

- wymagana moc dla pociagu ciagniętego lokomotywą wyznaczona dla prędkości $200 \mathrm{~km} / \mathrm{h}$ wynosi 4.6 MW i odpowiada mocom zainstalowanym w dostępnych na rynku lokomotywach na taką prędkość [5],

- wymagana dla pociaggu klasycznego dla uzyskania prędkości ok. $300 \mathrm{~km} / \mathrm{h}$ moc prawie $14 \mathrm{MW}$ możliwa jest do uzyskania tylko w układzie napędowym 8 osi napędnych, czyli z dwoma lokomotywami $7 \mathrm{MW}$, praktycznie nie dostępnymi w chwili obecnej na rynku,

- ze względu na duże zainstalowane moce i warunki przyczepności konieczne jest stosowanie $\mathrm{w}$ pociagach zespołowych wielu osi napędnych (moc napędowa rozproszona), tak jak to ma miejsce np. w pociagach serii 300 „Nozomi”.

Wnioski bardziej ogólne wynikające z przedstawionego materiału są jak zestawiono poniżej:

- moc niezbędna do prowadzenia pociągów wysokich prędkości wynosi znacznie powyżej $10 \mathrm{MW}$,

- jeśli uznać, że prądem granicznym do przeniesienia przez ruchomy styk pantograf - sieć trakcyjna jest obecnie na PKP PLK 2200 A, to pierwszym istotnym ograniczeniem do budowy sieci kolejowej na wysokie prędkości jest napięcie sieci trakcyjnej. Sieć $3 \mathrm{kV}$ dla prędkości dochodzących do $300 \mathrm{~km} / \mathrm{h}$ jest niewydolna, co potwierdza budowanie takich systemów na napięcie $25 \mathrm{kV}$ nawet w krajach z rozwiniętą siecią $3 \mathrm{kV}$ (np. Hiszpania),

- przy wyborze napięcia zasilania sieci trakcyjnej, ograniczając ten wybór z przyczyn podanych wyżej do $15 \mathrm{kV}-16.6 \mathrm{~Hz}$ i $25 \mathrm{kV}-50 \mathrm{~Hz}$, należy mieć na uwadze nie tylko problemy związane $\mathrm{z}$ dystrybucja energii $\mathrm{w}$ podstacjach zasilających sieć trakcyjna, ale także różnice w wielkości strat, zależnych od poziomu napięcia i częstotliwości, w obwodach elektrycznych pojazdów trakcyjnych,
- rozwiązania konstrukcyjne urządzeń elektrycznych zabudowywanych na pojeździe, szczególnie tych które wpływają na sprawność ogólną pojazdu, muszą być w sposób szczególny ukierunkowane na minimalizowanie strat, bowiem każdy stracony procent sprawności to ponad $100 \mathrm{~kW}$ straconej mocy, a ponadto konieczność zabudowywania kosztownych systemów chłodzenia efektywnie odprowadzających ciepło powstałe $\mathrm{z}$ tych strat.

Niezależnie od wszystkich poruszonych w niniejszym artykule aspektów związanych $\mathrm{z}$ mocą wymaganą przez pociagi zespołowe wysokich prędkości niezbędnej do uzyskania określonych parametrów rozruchu, prędkości maksymalnej, zdolności pokonywana wzniesień itp., przy projektowaniu sieci zasilających należy wziąć pod uwagę znacznie więcej parametrów niż tylko moc zainstalowana na pojeździe. Na parametry sieci i podstacji zasilających systemu kolei wysokich prędkości znaczący wpływ będzie miała organizacja ruchu pociagów na tych liniach, zarówno ta $\mathrm{w}$ pierwszych latach istnienia systemu i ta późniejsza, w okresie pełnego rozwoju tego rodzaju transportu.

\section{LITERATURA}

[1] Badania oporów ruchu wagonów pasażerskich. Opracowanie COBiRTK nr 3509/17. Warszawa 1980 (niepublikowane)

[2] Bendel H.: Elektrische Triebfahrzüge. VEB Verlag für Verkehrswesen. Berlin 1981

[3] Bogott H.: Anforderungen an Triebfahrzüge höherer Geschwindigkeiten. Schienenfahrzeuge 1990 nr 3

[4] Durzyński Z.: Elektryczny uktad lokomotywy 110 E. Materiaty VI Konferencji Naukowej Trakcji Elektrycznej SEMTRAK'94. Politechnika Krakowska, Kraków Zakopane 1994

[5] Durzyński Z., Marciniak Z.: Nowoczesne lokomotywy na prędkość powyżej $200 \mathrm{~km} / \mathrm{h}$. Materiaty Międzynarodowej Konferencji Naukowo-Technicznej SEP SITKom. Szklarska Poręba 1993

[6] Durzyński Z.: Dobór napędu zespołów trakcyjnych pradu statego metoda symulacji przejazdów. Rozprawa doktorska. Politechnika Poznańska 1988

[7] Frontczak F.: Porównanie systemu trakcji elektrycznej $25 \mathrm{kV}$ pradu przemiennego z systemem $3 \mathrm{kV}$ pradu statego dla szybkości powyżej $200 \mathrm{~km} / \mathrm{h}$. Materiaty Międzynarodowej Konferencji Naukowo-Technicznej SEP - SITKom. Szklarska Poręba 1993

[8] Gasowski W.: Calculation of motion aerodynamic of rail vehicles incorporated in a draft of cars. Archives of Transport 1993 vol. 6 issue 1-4, Warsaw

[9] Harrasek A., Rabsztyn M., Raczyński J.: Rozwój konstrukcji pociagów TGV. Technika Transportu Szynowego $2006 \mathrm{nr} 10$

[10] Ishikawa s.: Shinkansen-Triebzüge Serii 300 "Nozomi”. Elektrische Bahnen 1994 nr 8 
[11] Kałuża E.: Zbiór zadań i ćwiczeń projektowych z trakcji elektrycznej. Skrypty uczelniane. Nr 1848. Politechnika Ślaska. Gliwice 1994

[12] Krettek O., Grajnert J.: Zur luftfeder und schwingungstechnischen Auslegung des TGV-Atlantique. ZEV Glasers Annalen 1996 nr 8

[13] Lößel W., Landwehr H., Prem J.: ICE 3® - Die neue Generation der europäischen Hochgeschwindigkitszüge. ETR $1997 \mathrm{nr} 9$

[14] Nielsen N. T., Fischer H.: Der neue Triebzug IC3 der Dänischen Statsbahn, ein Konzept für die Zukunfk. ETR 1990 nr 1-2

[15] Nowak S.: Wagon osobowy bezprzedziałowy o prędkości $200 \mathrm{~km} / \mathrm{h}$ dla PKP. Technika Transportu Szynowego $1996 \mathrm{nr} 9$

[16] Peters J. L.: Aerodynamischer Wiederstand von Hochgeschwindigkeitsbahnen. VDI-Benchte $n r$ 635, 1987

[17] Podoski J. i inni: Teoretyczne zagadnienia trakcji elektrycznej - trakcja miejska i kolejowa. WNT Warszawa 1975
[18] Podoski J.: Zasady trakcji elektrycznej. WKE, Warszawa 1967

[19] Raczyński J.: Pociagi dużych prędkości - kierunki rozwoju. Technika Transportu Szynowego 2005 nr 5-6

[20] Rahn T., Kurz H.: InterCityExpress - High-Tech auf Schienen. ETR 1991 nr 5-6

[21] Rieger H., Landwehr H., Cuylen J.: Der neue Hochgeschwindigkitszüge AVE S103 der RENFE. ZEV. Glasers Annalen 2002 nr 10

[22] Romaniszyn Z.: Charakterystyki pociagów dużych prędkości i cechy konstrukcji ich podwozi. Technika Transportu Szynowego 1999 nr 5

[23] Romei R.: Italianischer Hochgeschwindigkeitszug ETR500 - Evolition des Projekts. ETR 1992 nr 12

[24] Sachs K.: Elektrische Triebfahrzüge. Sprinter Verlag. Wien, New York 1973

[25] Wolfram T.: Nowoczesne pojazdy spalinowe kolei europejskich. Technika Transportu Szynowego 1995 nr 6-7

[26] Żurkowski A.: Koleje dużych prędkości we Włoszech. Technika Transportu Szynowego 2006 nr 3. 